\title{
To study the parenting styles of mothers of early adolescents
}

\author{
Shreya Mehta and Garima Babel
}

Received: 28.01.2020; Revised: 13.03.2020; Accepted: 28.04.2020

See end of the paper for authors' affiliations Shreya Mehta

Department of Home Science, Faculty of Social Science and Humanities, Bhupal Nobels' University, Udaipur (Rajasthan) India

Email : shreya91mehta@gmail. com
ABSTRACT : The present study was undertaken to assess the parenting styles of mothers of early adolescent. The study was conducted in the municipal limits of Udaipur city. The total sample comprised of 120 mothers of early adolescents belonging to middle income group. Parenting style questionnaire, developed by Robinson et al. (1995) was modified and used for data collection. The results revealed that mothers of early adolescents followed authoritative parenting style.

KEY WORDS: Mothers, Parenting styles, Adolescence

- HOW TO CITE THIS PAPER : Mehta, Shreya and Babel, Garima (2020). To study the parenting styles of mothers of early adolescents. Asian J. Home Sci., 15 (1) : 66-68, DOI: 10.15740/HAS/AJHS/15.1/6668. Copyright@ 2020: Hind Agri-Horticultural Society. 